\title{
Compreendendo o papel dos sujeitos no ato de linguagem: estudo de caso das manifestações de 15 de março de 2015 no Twitter
}

\section{Understanding the role of the subjects in the speech act: a case study of the manifestations of March 15, 2015 on Twitter}

Poliana Lopes ${ }^{1}$
Denise Castilhos de Araújo²

Resumo Este artigo analisa as hashtags usadas em interações publicadas no Twitter nas manifestações de 15 de março de 2015 e a resposta dada pela presidente Dilma Rousseff e o governo em pronunciamento à imprensa, buscando definir os sujeitos do ato de linguagem, estabelecer seu papel e verificar a efetivação do contrato de comunicação. Esta pesquisa apresenta reflexões de Lévy e Lemos (2010), Santaella e Lemos (2010) e Israel (2010) sobre redes sociais digitais e Twitter; e Charaudeau (2014) sobre contrato de comunicação, ato de linguagem e seus sujeitos. A partir da análise, percebe-se que os eleitores estão exteriores à configuração verbal, assumindo o papel de EUc e deixando para as hashtags o de EUe; a presidente Dilma é o TUd e o governo, o TUi. Também se constata que o contrato de comunicação foi firmado, pois o TUi reconhece as mensagens do EUc.

Palavras-chave: Análise do discurso; Política; Redes sociais digitais; Sujeito; Twitter

\footnotetext{
1 Universidade Feevale, Porto Alegre, RS, Brasil. E-mail: poli.lopess@gmail.com

2 Universidade Feevale, Porto Alegre, RS, Brasil.

E-mail: deniseca@feevale.br
} 
Abstract This article analyzes the hashtags used in the interactions posted on Twitter in the manifestations of March 15, 2015 as well as the answer given by the President Dilma Rousseff and by the government in a statement to the press, seeking to define the subject of the speech act, establish their role and verify the effectiveness of the communication contract. This research presents reflections of Lévy and Lemos (2010), Santaella and Lemos (2010) and Israel (2010) on digital and social networks, such as Twitter; and Charaudeau (2014). Through the analysis, it is clear that voters are outside the verbal configuration, thus assuming the role of EUc and leaving the hashtags paper EUe; President Dilma is TUd, and the government, TUi. It is also notable that the communication contract was established because the TU recognizes the messages that the EUc.

Keywords: Discourse analysis; Digital social networks; Politics; Subject; Twitter 


\section{Introdução}

Dados do Ibope (2014) informam que, no Brasil, 53\% da população acessa regularmente a internet, que se tornou a primeira fonte para a busca por informações para $47 \%$ da população. O uso de redes sociais digitais também se destaca entre os objetivos dos brasileiros ao acessarem a internet, seja para relacionamento ou troca de impressões sobre assuntos diversos. Percebe-se que o espaço digital não serve apenas para troca de trivialidades, pois as pessoas também o usam para produção e publicação de conteúdo mais aprofundado, que qualifica o tipo de informação trocada.

Entre as redes sociais digitais com maior penetração do País, destaca-se o Twitter, reconhecido principalmente pelo caráter always on que a associação entre mobilidade e temporalidade permite, assim como a não necessidade de relação off-line.

Este artigo analisa as manifestações ocorridas no Brasil no dia 15 de março de 2015 sob a ótica das hashtags usadas nas mensagens postadas no Twitter e o pronunciamento do governo ocorrido no final do dia em entrevista coletiva. A escolha do Twitter deve-se ao caráter tempo real do microblogging, sua dinâmica móvel de uso e ao alcance das mensagens publicadas. O tema torna-se relevante na medida em que discute questões políticas e sociais que têm sido pauta de muitos veículos de comunicação. Considerando-se, então, que o acesso à internet e aos sites de redes sociais já atinge mais de $50 \%$ da população brasileira, que usa estes espaços para a defesa de pontos de vista e posicionamentos, inclusive políticos, entende-se como fundamental buscar um melhor entendimento das dinâmicas de conversação, assim como do posicionamento de seus usuários enquanto sujeitos de atos de linguagem.

Desta forma, busca-se responder quem são os sujeitos do ato de linguagem em conversas públicas nas redes sociais digitais e como eles se comportam dentro do ato. O objetivo é definir o papel dos sujeitos envolvidos no discurso (manifestantes virtuais e governo), analisar o ato de linguagem e a efetivação do contrato de comunicação formado entre eles. 
A partir do método monográfico, no qual se examina o tema visando observar todos os fatores que o influenciam, faz-se uma pesquisa descritiva (PRODANOV e FREITAS, 2013) a partir de técnicas padronizadas de coleta de dados. Como procedimento técnico, opta-se pela pesquisa bibliográfica a partir de Lévy e Lemos (2010a, 2010b), Santaella e Lemos (2010) e Israel (2010) para definir e caracterizar as redes sociais digitais e o Twitter; e Charaudeau (2014a, 2014b, 2014c) para analisar o contrato de comunicação e o ato de linguagem e seus sujeitos.

Faz-se também a análise de exemplos a partir de pesquisa documental, a partir dos 376 tweets publicados por brasileiros no Twitter marcados pelas 22 hashtags monitoradas ${ }^{3}$ em 15 de março de 2015 e a entrevista coletiva em resposta às manifestações realizada às $20 \mathrm{~h}$. As 22 hashtags foram selecionadas a partir das conversas visualizadas na semana anterior à manifestação e que, por isso, têm relação com a pauta das manifestações, tanto a favor quanto contra o governo.

Para dar conta dos objetivos apresentados, este artigo está dividido em três partes. A primeira apresenta a revisão teórica que conduzirá a análise do corpus, na qual se conceitua e caracteriza a Análise do Discurso e se define os sujeitos constitutivos do ato de linguagem. A segunda parte, também teórica, define e caracteriza o Twitter, rede social digital de onde os enunciados que compõem o corpus foram extraídos. Já na terceira parte faz-se a análise do corpus, a partir do entrecruzamento dos referenciais teóricos apresentados com o corpus.

\section{Compreendendo a análise do discurso}

Ao analisar um ato de linguagem é preciso, em primeiro lugar, ter em mente que um enunciado nunca é o primeiro, único, monológico. Como aponta Bakhtin (2010), toda palavra tem duas faces: ela é determinada pelo fato de proceder de alguém (EU, locutor) e ser dirigida a alguém (TU, ouvinte). Todo enunciado mantém relações com os enunciados produzidos anteriormente (relações interdiscursivas) e também

\footnotetext{
3 O monitoramento das interações a partir das hashtags foi realizado pelo software Seekr.
} 
com os enunciados futuros que os destinatários poderão produzir (relações interlocutivas), em um duplo dialogismo que faz o discurso escapar do enunciador, mesmo quando não há marcas linguísticas.

A escolha das palavras usadas em uma enunciação depende das relações sociais, pois ela é produto da interação de dois indivíduos socialmente organizados, o que faz com que sua estrutura só se torne efetiva entre falantes. Ou seja, esta escolha parte de um movimento dialógico, no qual o discurso encontra o discurso de outro e tem com ele relações vivas e intensas. Esta relação indica que o ato de linguagem é constituído de um explícito (manifestado) e de um implícito (lugar de sentidos múltiplos que dependem das circunstâncias de comunicação). Sua finalidade está além da configuração verbal, pois depende do jogo que o sujeito vai estabelecer entre esta e o implícito.

As circunstâncias do discurso intervêm na partilha do saber dos protagonistas da linguagem, enquanto sujeitos coletivos, em relação às práticas sociais. Elas abrangem o "conjunto dos saberes supostos que circulam entre os protagonistas da linguagem" (CHARAUDEAU, 2014b, p. 32), o que inclui as práticas sociais partilhadas e os filtros construtores de sentido. São eles que transformam o ambiente material em palavra e constroem a Situação Extralinguística - situação concreta que, segundo Bakhtin (2011), está vinculada diretamente à compreensão e explicação da comunicação verbal.

\section{Definindo os sujeitos do discurso}

Para compreender os papéis que os sujeitos protagonistas assumem no ato de linguagem estabelecido em relação ao corpus deste artigo, é preciso definir e compreender seus conceitos, assim como características e funções dentro do ato.

Ao retomar que a comunicação verbal ocorre entre duas pessoas (EU e TU), Bakhtin (2011) opõe-se aos estudos que tratam a relação entre os parceiros (locutor e ouvinte) como um ato passivo de percepção e compreensão por parte do ouvinte. Ele entende que esta forma não representa o todo na comunicação verbal, pois o ouvinte recebe e 
compreende a significação do discurso e tem em relação a ele uma atitude responsiva ativa, ou seja, ele concorda, executa e responde - ou não.

Como toda compreensão é passível de resposta, assim que é dado o enunciado o ouvinte (TU) torna-se o locutor (EU), movimento que delineia todo o ato de linguagem enquanto troca entre duas pessoas. Outro ponto destacado por Bakhtin (2011) é a possibilidade de o ouvinte não dizer ou fazer algo. Este ato, visto como uma resposta passiva (sem ação) é, na verdade, uma resposta ativa, pois ao não atender ao locutor o ouvinte também está se manifestando.

Ao desenvolver sua teoria da enunciação, Benveniste (1989) enfatiza que quando o locutor (EU) se apropria da língua, ele imediatamente reconhece o outro (ouvinte) diante de si, independente do grau de presença que atribua a ele. Neste contexto, ele define três categorias: pessoas (EU e TU enquanto sujeitos do ato que dividem o espaço do discurso e mantêm uma forte relação de identidade e alteridade; e um ELE, papel que cabe ao referente) que são interpeladas pela ideologia, tempo e espaço concretos, fazendo com que todo enunciado seja feito aqui e agora.

Todo ato de linguagem depende dos saberes supostos entre os protagonistas da linguagem, que são carregados de dimensões implícitas e explícitas. Tanto Bakhtin quanto Benveniste vão além do conceito comunicacional que reduz o ato de linguagem à relação Emissor -> Mensagem -> Receptor, pois este último não é passivo: ele constrói uma interpretação sobre o enunciado a partir de seu ponto de vista sobre as circunstâncias do discurso e também sobre quem enuncia (EU) e suas intenções.

Assim, há um TU-interpretante (TUi) que é diferente do TU-destinatário (TUd) ao qual o EU se dirige. Quando TUi interpreta o enunciado, ele tem uma imagem do EUc diferente da que o $\mathrm{EU}$ enunciador queria passar.

Esta compreensão faz do ato de linguagem uma atividade metalinguística dividida em dois processos entre quatro sujeitos: a Produção, na 
qual o EUe se dirige a um TUd que é idealizado pelo EUc; e a Interpretação, na qual o TUi constrói uma imagem do EUc do locutor.

A partir destes pontos apresentados por Charaudeau (2014b) pode-se estabelecer quem são os quatro sujeitos envolvidos no processo comunicacional:

- TUd - o TU destinatário é o interlocutor fabricado pelo EU como destinatário ideal, sobre o qual o EU tem domínio, transparente e entendido como o sujeito da fala.

- TUi - o TU interpretante age fora do ato de enunciação produzido pelo EU, sendo responsável pela interpretação do enunciado. Opaco, ele depende apenas de si e se institui no momento que interpreta.

- EUe - é o responsável pelo ato de fala e oculta, em maior ou menor grau, o EUc. Como o TUd, existe no e pelo ato de produção e interpretação.

- EUc - é o sujeito agente que se institui como locutor e articulador da fala, determinado como sujeito comunicante. Participa de todo o ato de linguagem, apesar de estar em posição de exterioridade em relação à configuração verbal do ato.

A concepção dos sujeitos de Charaudeau (2014b) ganha valor quando analisada dentro do ato de linguagem, no qual o sujeito assume seu papel e exibe suas principais características.

\section{O papel dos sujeitos no ato de linguagem}

Por não ser o resultado de uma única intenção do emissor nem resultar de um duplo processo simétrico entre Emissor e Receptor, o ato de linguagem caracteriza-se por ser maior do que um ato de linguagem. Isso porque, como afirma Charaudeau (2014a), ele resulta do jogo entre o implícito e o explícito e depende de circunstâncias de discurso específicas, do ponto de encontro entre os processos de produção e interpretação e é encenado por duas entidades enquanto sujeito de fala (EUe/EUc) e sujeito agente (TUd/TUi). 
$\mathrm{O}$ ato de linguagem e seus sujeitos pode ser entendido no esquema:

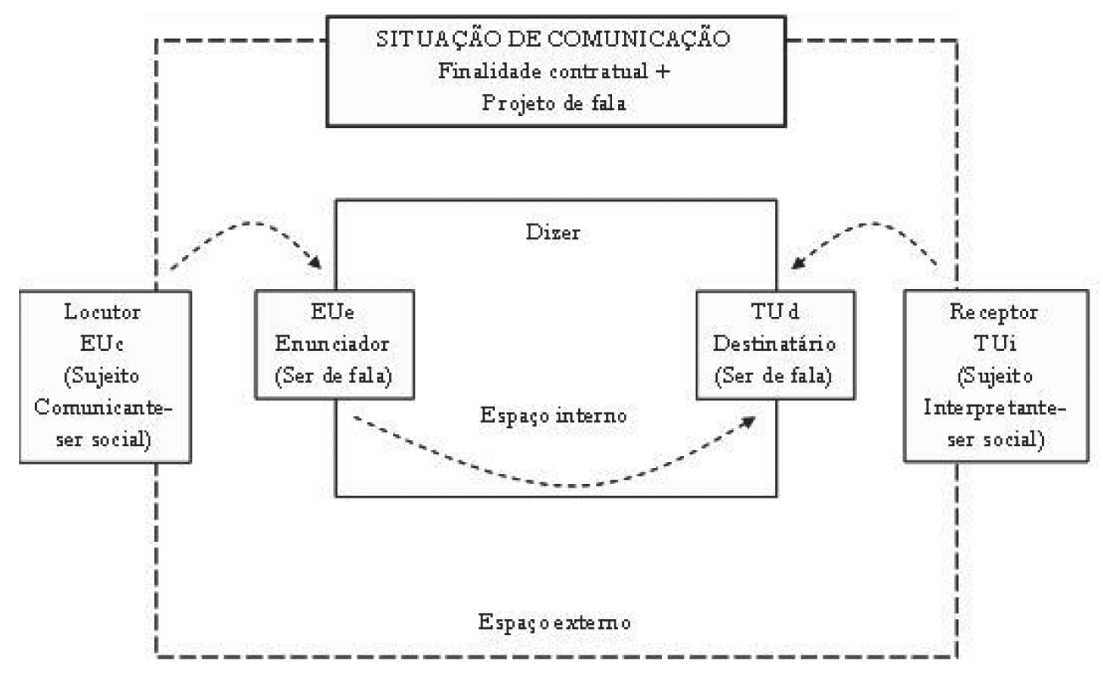

Figura 1. Representação do ato de linguagem Fonte: Charaudeau (2014c, p. 52).

Como mostra a Figura 1, todo ato de linguagem tem dois circuitos de produção de saber, definidos por Charaudeau (2014c) como o circuito interno da fala configurada (que reúne os seres de fala EUe e TUd, assim como a representação discursiva) e o circuito externo à fala configurada (representação da situação de comunicação, reúne os seres agentes instituídos como imagem de sujeito comunicante - EUc - e interpretante - TUi).

Na produção do ato de linguagem, é o EUc quem organiza, dentro de suas competências e restrições, o projeto global de comunicação pretendido. Ele objetiva que seu ato de linguagem tenha sucesso e, para isso, precisa que haja coincidência de interpretação entre o TUi e o TUd. Para isso, ele usará contratos e estratégias de comunicação.

O contrato de comunicação, segundo Charaudeau (2014c), pressupõe que indivíduos que participam de um mesmo corpo de práticas sociais possam chegar a um acordo sobre as representações linguageiras 
destas práticas. Para que isso ocorra, o EUc precisa fornecer elementos que permitam ao TUi reconhecer nas palavras empregadas o mesmo sentido dado pelo EUc, o que gera, por parte do TUd, a conivência ou concordância desejada pelo EUc.

Todo ato de linguagem depende de um contrato de comunicação, pois é ele que sobredetermina os protagonistas da linguagem em sua dupla existência de sujeitos agentes e sujeitos de fala e legitima a fala ao fornecer o estatuto sociolinguageiro aos sujeitos.

A estratégia, para Charaudeau (2014c, p. 56) baseia-se na hipótese de que

O sujeito comunicante (EUc) concebe, organiza e encena suas intenções de forma a produzir determinados efeitos - de persuasão ou de sedução - sobre o sujeito interpretante (TUi), para leva-lo a se identificar - de modo consciente ou não com o sujeito destinatário ideal (TUd) construído por EUc.

Desta forma, reforça-se que a comunicação está envolvida por uma dupla aposta: quem fala espera que seus contratos sejam bem percebidos pelo destinatário e também que suas estratégias produzam o efeito desejado. Esta dupla aposta converge em uma encenação, a qual é recebida e revista pelo sujeito interpretante, que detecta e interpreta a mensagem e pode reagir de três maneiras: não dominar completamente os efeitos produzidos pelo EUc; não dominar seu próprio inconsciente e transparecer evidências externas ao seu ato de linguagem, ou seja, reagir de forma inesperada ou não desejada; e compreender de forma equivocada o ato, por não estar consciente do contexto sócio-histórico que o iniciou.

Ao realizar a análise de um ato de linguagem, é preciso ir além da intenção do sujeito comunicante (EUc) ou da compreensão do sujeito interpretante (TUi), para fugir de uma visão simplista sob apenas um ponto de vista. É necessário dar conta dos possíveis interpretativos ${ }^{4}$ que surgem no encontro dos processos de produção e interpretação, respondendo "quais sujeitos o texto faz falar?".

\footnotetext{
${ }^{4}$ Como o ato de linguagem passa pelas práticas sociais de um grupo, constitui as representações linguageiras das experiências de seus indivíduos. Ao analisar os elementos linguageiros, semânticos e formais que o compõem, faz-se surgir os possíveis interpretativos (CHARAUDEAU, 2014c).
} 


\section{Redes sociais digitais e as conversas no twitter}

Atualmente, $53 \%$ da população brasileira têm acesso regular à internet, segundo o Ibope. A internet é, hoje, a primeira fonte acessada na busca por informações, para $47 \%$ da população. Entre os jovens de 15 a 32 anos, $90 \%$ da população acessa a internet regularmente, 93\% navegam em sites de redes sociais e $43 \%$ consideram a internet sua principal fonte de entretenimento.

As redes sociais digitais demonstram a "extraordinária capacidade dos indivíduos em gerar, difundir e trocar significados na comunicação interpessoal coletiva, em um sistema massivo de rede e em tempo real, no qual tudo tende a estar conectado" (GARCIA, DALY e SUPOVITZ, 2015 , p. 55, tradução nossa).

A organização das redes sociais digitais é feita em categorias, que incluem as plataformas de social networking (Facebook, LinkedIn), microbloging (Twitter), fotografia (Flickr, Instagram, Pinterest), vídeo (YouTube, Vimeo), social news (Digg, Reddit), transmissão em streaming (Periscope, Meerkat, Ustream), social gaming (World of Craft), bookmarking (Delicious, StumbleUpon) e blogs (Wordpress, Blogger), entre outras.

Lemos e Lévy (2010b) apontam que o uso das redes sociais digitais não pode ser resumido à troca de banalidade, pois se percebe um crescente uso e uma produção de conteúdo que tende a elevar a qualidade das informações trocadas entre os usuários. A ampliação de seu uso é a responsável por uma onda ainda não perfeitamente mensurável, definida pelos autores como a "liberação da emissão", que inclui não só a palavra escrita, mas também sons, fotos e vídeos que são distribuídos livremente entre pessoas. Esta liberação da expressão, que exclui o filtro de um profissional mediador (como os jornalistas), pode ser apontada como a principal vantagem da internet em relação às mídias tradicionais.

Este artigo tem como objeto de análise as interações publicadas no Twitter durante as manifestações ocorridas no Brasil em 15 de março de 2015, o que torna necessário compreender esta mídia social, suas dinâmicas e particularidades, o que será feito a seguir. 


\section{Twitter: a rede social digital das conversas em tempo real}

Entre as redes citadas, este artigo destaca o Twitter, site de rede social gratuito no qual os usuários escrevem mensagens de até 140 caracteres (tweets), que são enviadas para seguidores (followers) que optaram por receber o conteúdo. Um tweet permite a adição de texto, imagem, vídeo, links e também hashtags, que são palavras ou frases precedidas pelo símbolo \#, que converte o texto em metadado. Usar as hashtags permite a indexação de determinada temática, visando à verificação quantitativa e a compreensão qualitativa das informações do restante do conteúdo do tweet que está associado a elas.

Twitter é atualmente a mídia social mais rápida, simples e econômica, pela qual circula todo o tipo de informação, notícias, ideias, eventos, boatos, materiais multimídia, etc., emitidos a partir de qualquer ambiente profissional ou outras mídias sociais em tempo real. Assim, no Twitter cruzam tanto os meios profissionais da comunicação social (televisão, jornais, revistas, rádio etc.) quanto qualquer outra mídia social (Facebook, Instagram, Youtube, Flickr, blogs, fóruns etc.), parte de um vasto registro de tipos de perfis de usuário (indivíduos, ONGs, instituições governamentais, meios de comunicação, grupos de pressão, os periódicos científicos, empresas, marcas etc.) (GARCIA, DALY E SUPOVITZ, 2015, p. 57, tradução nossa).

A dinâmica de uso do Twitter inclui ainda retweets (ou RT, que é a replicação do conteúdo de terceiro para a rede de seguidores do usuário, que pode agregar ou não novo conteúdo), reply (resposta), mentions (citação de determinado usuário no texto de um tweet), likes (quando o receptor "curte" o conteúdo recebido), blocks (quando um usuário bloqueia outro, que não poderá mais receber seu conteúdo nem contatá-lo), listing (incluir o emissor em listas temáticas criadas pelo receptor para organizar o conteúdo), Direct Messages (ou DMs, são mensagens privadas para um usuário ou grupo).

Israel (2010, p. 5) destaca os diferentes interesses e objetivos dos usuários do Twitter: "as pessoas tuitam para arrecadar contribuições para 
uma causa, para fazer o governo tomar uma atitude, para encontrar e distribuir notícias; para construir redes pessoais ou profissionais ou apenas para matar um pouco de tempo com as pessoas que mais gostam".

Segundo Santaella e Lemos (2010a), um importante diferencial do Twitter é que ele une a mobilidade (permitida pela associação do crescimento do número de smartphones ativos às melhorias de sinal de internet móvel) à temporalidade do caráter always on ${ }^{5}$ inerente às redes sociais 3.0. Ele é "uma verdadeira ágora digital global: universidade, clube de entretenimento, ‘termômetro’ social e político, instrumento de resistência civil, palco cultural, arena de conversações contínuas” (SANTAELLA e LEMOS, 2010a, p. 66).

O fluxo informacional do Twitter ocorre em duas vias: o inflow considera o conteúdo selecionado pelo usuário para ser recebido, enquanto o outflow abrange o conteúdo que será divulgado pelo usuário, que depende da análise da sua estratégia pessoal.

As trocas podem gerar o que Lemos e Lévy (2010a) definem como comunidade virtual: grupo de pessoas que se relacionam no ciberespaço. Além da estrutura técnica da rede de computadores, as comunidades virtuais dependem da existência de interesses compartilhados, intimidade e perenidade nas relações. Assim, há nas redes sociais digitais de relações comunitárias (em que há um território simbólico e uma afinidade entre seus membros, como no Facebook, que se baseia mais nas relações de amizade) e não comunitárias (local de encontro e compartilhamento de informações e experiências mais efêmeras e desterritorializadas, como no Twitter, onde as trocas ocorrem principalmente por afinidades por temas e não por um relacionamento prévio).

Ou seja, o Twitter destaca-se por privilegiar a qualidade e o tipo de conteúdo veiculado por um usuário específico, independente de relação social off-line. Isso porque "o Twitter serve como um meio multidirecional de captação de informações personalizadas; um veículo de difusão contínua de ideias; um espaço colaborativo, no qual questões [...] podem ser livremente debatidas e respondidas" (SANTAELLA e LEMOS,

${ }^{5}$ Sempre conectado, em tradução livre. 
2010a, p. 66) Com isso, o Twitter reforça a ideia de desterritorialização do "eu" de Lemos e Lévy (2010b, p. 202):

Ele (o eu) está cada vez menos ligado a uma localização física, a uma classe social, a um corpo, um sexo, ou a uma idade. [...] Devemos compreender como mostram diversos estudos sobre a subjetividade e a cultura contemporânea, que nossa identidade se ligará diferentemente aos nossos conhecimentos, centros de interesse, competências sociais e linguísticas. Nosso "corpo informacional", virtualmente onipresente, se define cada vez mais por suas coordenadas no espaço semântico.

No mundo, o Twitter tem 241 milhões de usuários ativos por mês, os quais publicam 500 milhões de tweets por dia. O Brasil é o quinto país em total de participantes, com cerca de 10 milhões de usuários ativos. Este número representa cerca de $5 \%$ da população brasileira - ou 9,4\% dos usuários de internet no país. Deste total, 65\% acessa o microblogging por celular ou tablet (no mundo, este índice chega a 76\%), o que enfatiza o caráter móvel e a comunicação em tempo real da rede. Um dado interessante é que $40 \%$ dos usuários ativos nunca tuitam, apenas consomem conteúdo, ou seja, privilegiam o inflow.

Assim como as outras redes, o Twitter é uma fonte de dados produzidos de forma ubíqua, incessante e massiva, os quais são definidos como Big Data. Este conjunto de dados oferece uma grande oportunidade de pesquisa e análise, visto que além de seu valor quantitativo carregam em si opiniões, o que permite uma análise qualitativa destas opiniões e de sentimentos, desejos e demandas.

\section{Procedimentos metodológicos}

Neste artigo, segundo Prodanov e Freitas (2013), aplica-se uma pesquisa descritiva, na qual os fatos são observados, registrados, analisados, classificados e interpretados sem interferência ou manipulação do pesquisador sobre o fenômeno. Este tipo de pesquisa usa técnicas padronizadas de coleta de dados. Neste artigo, optou-se pela observação sistemática a partir do monitoramento das redes sociais digitais via software específico. 
Como procedimento técnico, opta-se pela pesquisa bibliográfica e pela análise de exemplos a partir de pesquisa documental. O corpus é composto por publicações de brasileiros no Twitter no dia 15 de março de 2015, durante as manifestações contra o PT e o governo Dilma Rousseff. A escolha do corpus deve-se ao fato de ser o Twitter a rede social digital que melhor se relaciona com eventos em tempo real. O caráter always on do microblogging soma-se à mobilidade, destacada por Santaella e Lemos (2010a) como fator de destaque.

Para a coleta dos dados (tweets) optou-se pelo Seekr, software de monitoramento de redes sociais digitais. Nele, foram cadastradas 22 hashtags selecionadas previamente a partir do monitoramento da rede durante a semana antes do evento. A análise partirá da mensuração, nos tweets coletados a partir das hashtags pré-selecionadas, das menções das hashtags selecionadas a favor e contra o governo e a presidente Dilma, o que permitirá listar o posicionamento político das pessoas que se manifestaram via rede social digital.

Ao mesmo tempo, serão analisadas as falas dos ministros José Eduardo Cardozo (Justiça) e Miguel Rossetto (Secretaria-Geral da Presidência da República), na entrevista coletiva realizada na noite de 15 de março, visando determinar se houve o entendimento do posicionamento popular por parte do governo vigente no período e se foi firmado o ato de linguagem. Assim, será possível identificar os sujeitos enunciadores (EUe e EUc) e o papel da presidente Dilma e do governo enquanto sujeitos receptores.

\section{Definição dos sujeitos no ato de linguagem e do contrato de comunicação}

Antes de destacar as manifestações populares de 15 de março de 2015, é importante discutir a presença deste tipo de evento na história do país. Nas últimas sete décadas, a população uniu-se para ir às ruas protestar em pelo menos cinco momentos cruciais para o país. 
No início dos anos 1960, por exemplo, a Batalha da Legalidade, liderada por Leonel Brizola, promoveu grandes manifestações populares em Porto Alegre (RS) em defesa da posse de João Goulart como presidente da República, que ocorreu em 1961. Na mesma época, houve "um avanço dos movimentos sociais e o surgimento de novos atores" (FAUSTO, 1995, p. 443), como a criação das ligas camponesas e o fortalecimento do movimento sindicalista. Além disso, "os estudantes, através da UNE, radicalizaram suas propostas de transformação social e passaram a intervir diretamente no jogo político" (FAUSTO, 1995, p. 445).

Em oposição ao governo de João Goulart e seus atos de reforma (como a reforma agrária e a reforma urbana), ocorreram mobilizações populares como a Marcha da Família com Deus e pela Liberdade (SP), que reuniu cerca de 500 mil pessoas, em uma "demonstração de que os partidários de um golpe poderiam contar com uma significativa base social de apoio" (FAUSTO, 1995, p. 460). Segundo Fausto (1995, p. 465),

o movimento de 31 de março de 1964 tinha sido lançado aparentemente para livrar o país da corrupção e do comunismo e para restaurar a democracia, mas o novo regime começou a mudar as instituições do país através de decretos, chamados de Atos Institucionais (AI).

Com os Atos Institucionais e o crescimento da repressão, houve a diminuição dos movimentos populares, que se seguiu até o fim dos anos 1970 e início dos 1980, com a Anistia e o fim do Regime Militar. Em 1984, 20 anos depois, a população retornou às ruas em várias cidades brasileiras para pedir eleições diretas para presidência da República (Movimento Diretas Já!), o que acabou não se concretizando naquele ano, mas que reuniu, em atos como o do Rio de Janeiro e de São Paulo, mais de um milhão de pessoas (ARTIGO 19, 2014).

Em 1992, ou seja, oito anos após as Diretas Já!, houve novas mobilizações de rua, nesse momento, contra o governo do presidente Fernando Collor. Na época, a 
expressão máxima foram os caras pintadas - estudantes que pintavam os rostos de verde e amarelo nas manifestações - e que também levaram milhares de pessoas às ruas em várias manifestações pelo País, contribuindo para a renúncia do presidente, seguida por um impeachment decretado pelo Senado Federal (ARTIGO 19, 2014).

Também é fundamental destacar que, neste período, houve muitas ações de movimentos específicos, a partir de recorte de classes e grupos sociais, como os comícios e mobilizações dos metalúrgicos no ABC Paulista nos anos 1980, assim como dos professores estaduais em diferentes Estados. Mais recentemente, destacam-se a "Marcha Nacional pela Reforma Agrária, Emprego e Justiça” (1997), caminhada que partiu de três pontos diferentes do País, em direção a Brasília e que reuniu centenas de milhares de pessoas; a "Marcha dos Cem Mil” (BRASÍLIA, 1999) criticando a política econômica do presidente Fernando Henrique Cardoso e a corrupção no governo federal; a "Marcha da Liberdade" (2011, em 41 cidades do país) contra a repressão policial aos movimentos sociais em manifestações, as "Marchas das Vadias" em defesa dos direitos das mulheres; as "Paradas do Orgulho Gay" em defesa dos LGBT, que tem, inclusive, um calendário das passeatas em várias cidades do país.

Em 2013, 21 anos após os caras pintadas, além das manifestações citadas anteriormente, os atos organizados pelo Movimento Passe Livre (MPL, movimento horizontal sem lideranças formais) centralizaram o processo de mobilização popular daquele ano. A partir do anúncio de aumento nas tarifas do transporte público de várias cidades do País, ocorreram protestos convocados pelo MPL, especialmente em Porto Alegre, Rio de Janeiro e São Paulo. O “4 Grande Ato contra o Aumento das Passagens", ocorrido no dia 13 de junho em São Paulo, reuniu cerca de 20 mil pessoas; do ato seguinte, no dia 17 de junho, participaram mais de 100 mil pessoas (tanto em São Paulo quanto no Rio de Janeiro, segundo os organizadores), redimensionando a opinião pública sobre as manifestações.

Após as manifestações, o aumento das tarifas foi revogado em várias cidades do País, indicando uma vitória das mobilizações populares. 
Entretanto, os protestos foram mantidos, com a população indo às ruas com uma pauta mais difusa, expressando insatisfação com a falta de serviços públicos de qualidade:

Depois da revogação do aumento das passagens, o MPL não continuou convocando todos os outros protestos subsequentes. As manifestações eram compostas por inúmeros grupos, de organizações diferentes, mas nenhum deles teve condições de assumir um papel de protagonista dessas manifestações, a ponto de seus líderes serem reconhecidos como representantes de todo o movimento de junho. Outra particularidade foi a difusão de pautas e a falta de clareza nas reivindicações, que marcaram as manifestações em 2013, depois da revogação das tarifas. [...] As manifestações em 2013 tiveram, como um dos pontos centrais, a não aceitação do sistema político representativo como um interlocutor legítimo, ocorrendo atos de rechaço, em várias manifestações, à participação de partidos políticos, até mesmo de partidos historicamente ligados às lutas sociais e às pautas centrais dos protestos. (ARTIGO 19, 2014)

Em 2015, novas manifestações tomaram as ruas do País, essas contrárias à presidente Dilma Rousseff e o governo do PT, reeleito em 2014. A manifestação de 15 de março de $2015^{6}$, diferente das anteriores, "chamou atenção por seu caráter nacional: todas as capitais do país e mais o Distrito Federal tiveram protestos que, sobre a égide de uma luta contra a corrupção, visava atacar a presidente Dilma Rousseff (PT)" (GUTEMBERG e LEAL, 2015). Também em 2015, os estudantes de escolas públicas de São Paulo iniciaram um movimento de ocupação de suas escolas, reivindicando melhores condições de estudo e de trabalho para os professores (ARTIGO 19, 2014), tipo de ato que vem sendo, em 2016, também realizado em outros Estados.

O interesse deste estudo recai sobre as consequências dos protestos de 2015, os quais reuniram, segundo os jornais O Globo e Estadão (2015), quase dois milhões de pessoas nos 26 Estados e Distrito Federal, incluindo todas as capitais. Já a Folha de S. Paulo (2015) enfatiza que foram

\footnotetext{
6 Para apuração das informações referentes às manifestações, optou-se pelas reportagens publicadas nos sites dos três jornais com maior circulação da edição digital (MÍDIA DADOS, 2014): Folha de S. Paulo (54,93 mil exemplares), Estadão (46,05 mil) e O Globo (39,38 mil).
} 
um milhão de manifestantes. Quanto ao número de municípios com protestos, os três jornais divergem: a Folha aponta 152 municípios, o Estadão informa 185 e O Globo cita 147. Segundo o Datafolha, esta foi a maior manifestação no Brasil desde o movimento Diretas Já, em 1984 (O ESTADO DE S. PAULO, 2015).

Os três jornais destacam que o verde e amarelo deu o tom dos protestos. A Folha (2015) diz que o discurso dos manifestantes pedia o impeachment da presidente Dilma e acusava o PT pelos casos de corrupção na Petrobras. A estes motivadores, o Estadão e O Globo (2015) acrescentam as reclamações sobre a situação política, econômica, o antipetismo e, em alguns momentos, o pedido de intervenção militar.

Em artigo que analisa a influência das manifestações de 15 de março de 2015 nas postagens feitas pela presidente Dilma Rousseff em sua página no Facebook entre 15 de fevereiro e 29 de março, Soares (2015, p.5) detalha que

Os protestos foram organizados por grupos que estavam insatisfeitos com o governo de Dilma. O tema da corrupção foi amplamente lembrado. O pedido de impeachment da presidente foi um ponto comum às manifestações. A economia também foi foco de alguns manifestantes. Ainda houveram algumas reinvindicações de grupos menores, como o pedido por intervenção militar, por exemplo.

Peruzzo (2013, p. 77) destaca que os movimentos de junho de 2013 e também o de 15 de março de 2015 não são movimentos sociais, mas, sim, movimentos político-ideológicos que lutam "por participação política, protestos por antagonismos políticos, reivindicações por democracia, mudança de regime", entre outras bandeiras.

O monitoramento realizado via software Seekr no Twitter, durante o dia 15 de março, resultou em 376 menções das hashtags selecionadas. Considerando-se que este artigo define como ponto de partida as hashtags utilizadas nas mensagens publicadas no Twitter com relação à manifestação pública, os marcadores foram classificados como positivos (concordam com as manifestações, opondo-se ao governo vigente); negativos (defendem ou apoiam a presidente e o governo e discordam 
das manifestações); e neutros (sem identificação favorável ou contrária). Desta forma, chega-se a seguinte divisão e quantificação:

- 15 hashtags positivas, com 288 menções: \#15demarco, \#antipt, \#chegadecorrupcao, \#foracorruPTos, \#foraDilma, \#foraPT, \#impeachment, \#impeachmentDilma, \#intervencaomilitar, \#mudaBrasil, \#panelaço, \#ptnuncamais, \#reformapolitica, \#vemprarua e \#vemprarual 5 demarco.

- Três hashtags neutras, com 52 menções: \#Dilma, \#DilmaRousseff, \#menosodiomaisdemocracia.

- Quatro hashtags negativas, com 36 menções: \#dilmafica, \#DilmalindaoBrasilteama, \#domingoeunaovouporque, \#Globogolpista.

A partir do uso das hashtags, pode-se estabelecer que entre os usuários que usaram um marcador para fazer parte da conversa e, ao mesmo tempo, emitir sua opinião, $76,5 \%$ se posicionam a favor das manifestações e contra o governo, 9,7\% estão a favor do governo e contrários às manifestações e 13,8\% de forma neutra. Entre as hashtags positivas, a mais usada foi \#vemprarua (168 menções), que além de ser um convite distribuído via outflow, é também uma apropriação da palavra de ordem das manifestações ocorridas no Brasil em julho de 2013.

Forma-se, assim, o que Lemos e Lévy (2010b) definem como micronações virtuais, aquelas formadas por pessoas conectadas por interesses, sem necessariamente estarem no mesmo território. No caso das manifestações, todas as pessoas estão no mesmo País, mas o uso das hashtags permite extrapolar os limites entre os Estados e acompanhar, em tempo real, as manifestações em outros locais (inclusive no exterior).

A análise do uso das hashtags leva à reflexão sobre seu papel enquanto sujeito no ato de linguagem e permite a elaboração de uma nova representação do ato (Figura 2): 


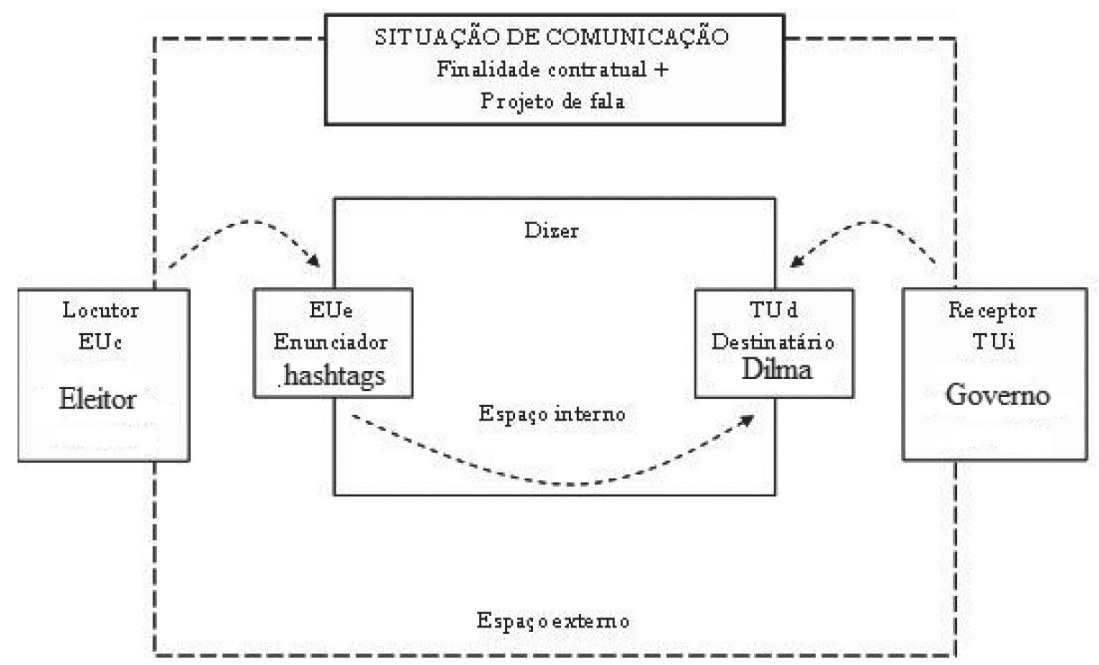

Figura 2. Representação do ato de enunciação das hashtags em 15 de março de 2015

Fonte: Elaborado pela autora a partir de Charaudeau (2014c).

A Figura 2 identifica as hashtags como EUe e as vozes por trás do enunciador (os brasileiros que unificam seu discurso pelas hashtags) como EUc. É possível chegar a este entendimento quando se estabelece que o Twitter é um canal de discussões colaborativo no qual se expressam ideias e sentimentos nas conversas e no qual são trocadas e consumidas informações em tempo real. A publicação de uma mensagem no Twitter não depende de conhecimento prévio entre os sujeitos, ou seja, esta rede social digital é uma comunidade virtual não comunitária, definida por Lemos e Lévy (2010a) como um local de encontro e compartilhamento desterritorializado, onde as trocas ocorrem por afinidade por temas.

Outro fator que colabora com este entendimento é a encontrabilidade das informações. Havendo interesse em um tema específico, não há como buscar as publicações de cada usuário que fale individualmente. Assim, a centralização das publicações a partir de hashtags permite o acompanhamento em tempo real do que é dito. Por isso, entende-se que 
a fala direcionada à presidente Dilma parte das hashtags enquanto EUe, pois elas ordenam e reúnem os enunciados (como uma voz única), que são estruturados pelo EUc, que reúne os brasileiros.

A presidente Dilma Rousseff, a quem as mensagens mediadas pelas hashtags se dirigem, assume o papel de TUd, de destinatário ideal fabricado pelo EUc. Hashtags como \#foraDilma e \#DilmalindaoBrasilteama marcam o destino das mensagens e colocam a presidente no ato de produção. A resposta do TUd depende do TUi, que interpreta os enunciados a partir de sua experiência pessoal. Considerando-se que o governo é um coletivo e que a presidente é sua representante, pode-se identificar o próprio governo como TUi.

$O$ fato de a presidente não responder aos manifestantes remete a Bakhtin (2011), que afirma que esta resposta passiva é ativa, pois não falar é uma forma do ouvinte se manifestar. Em seu lugar, participam da coletiva de imprensa os ministros José Eduardo Cardozo (Justiça) e Miguel Rossetto (Secretaria-Geral da Presidência da República), que saem do espaço externo da situação de comunicação, assumindo o papel de interlocutor dentro do ato de fala. Este novo posicionamento é ressaltado na fala dos ministros, que em diversos momentos usam frases como “a presidente Dilma acredita” para argumentar em nome dela.

$\mathrm{Na}$ coletiva, os ministros buscaram responder ao que foi tratado pela mídia durante o dia das manifestações e também mencionado nas postagens que continham as hashtags monitoradas, especialmente em relação às temáticas "corrupção", "reforma política" e as necessidades de mudanças no país (que apareceram também nos posts, com os marcadores \#chegadecorrupcao, \#reformapolitica e \#mudaBrasil), para as quais apresentaram medidas a serem implantadas pelo governo. Eles também repetiram, em diversos momentos, a importância da realização de manifestações de ordem democrática, legal e longe de alternativas golpistas, o que pode ser entendido como uma resposta às hashtags \#foracorruPTos (que enfatiza a sigla do PT no marcador, associando a corrupção ao partido), \#foraDilma, \#foraPT, \#impeachment, \#impeachmentDilma e \#intervencaomilitar, atos entendidos como antidemocráticos pelos 
interlocutores e que também tiveram presença marcante na mídia e nas ruas. Essa avaliação é feita a partir de suas interpretações de mundo, o que inclui posicionamentos políticos.

Assim, confirma-se a efetivação do contrato de comunicação de Charaudeau $(2014 \mathrm{c})$, pois se percebe que os sujeitos participantes do ato chegaram a um acordo. Ao empregar determinadas hashtags emissoras da mensagem (EUe), o eleitor (EUc) forneceu elementos que ajudaram o TU a reconhecer e concordar com o sentido dado pelo EUc.

\section{Considerações finais}

Com este artigo, buscou-se analisar as manifestações ocorridas no Brasil no dia 15 de março de 2015 sob a ótica das mensagens postadas no Twitter para compreender como o que é dito nesta rede através de hashtags estabelece quem são os sujeitos do ato de linguagem em conversas públicas nas redes sociais digitais e como eles se comportam dentro do ato. Para tanto, foram monitoradas as menções no Twitter a 22 hashtags no dia de manifestações.

Estabeleceu-se como objetivo definir o papel dos sujeitos envolvidos no discurso, sendo eles os manifestantes virtuais e a presidente Dilma, representante do governo federal. Ao verificar a relação das mensagens mediadas pelas hashtags e direcionadas à presidente, pode-se indicar os quatro sujeitos citados por Charaudeau (2014b, 2014c) para o ato de linguagem, sendo as hashtags o EUe, os brasileiros o EUc, a presidente o TUd e o governo o TUi.

Ao analisar o ato de linguagem, percebe-se que o contrato de comunicação foi firmado, pois durante a coletiva de imprensa os ministros responderam aos pontos destacados nas manifestações, pela mídia e também nas hashtags, com destaque para os marcadores relacionados ao combate à corrupção e a reforma política. Isto porque o TUi reconheceu e concordou com os elementos fornecidos pelo EUc nas mensagens emitidas pelo EUe.

A partir deste estudo é possível elaborar novas análises, utilizando-se de mensagens publicadas no Twitter em relação a outros eventos ou 
ainda publicações realizadas em outras redes sociais digitais, buscando compreender o papel e o valor das hashtags em cada uma delas. Como cada rede tem seu público, suas dinâmicas de uso e especificidades, este artigo pode servir como parâmetro de comparação com outras realidades.

\section{Referências}

ARQUIVO 19. Protestos no Brasil 2013. Publicado em jun. 2014. Disponível em: http:// www.artigo 19.org/protestos/. Acesso em: 21 jun. 2016.

BAKHTIN M. M. A interação verbal. In: Marxismo e filosofia da linguagem: problemas fundamentais do método sociológico da linguagem. São Paulo: Hucitec, 2010.

BAKHTIN M. M. Os gêneros do discurso. In: Estética da criação verbal. São Paulo: WMF Martins Fontes, 2011.

BENVENISTE, E. O aparelho formal da enunciação. In: Problemas de linguística geral II. Campinas: Pontes, 1989.

CHARAUDEAU, P. O ato de linguagem como encenação. In: Linguagem e discurso: modos de organização. 2. ed. São Paulo: Contexto, 2014c.

CHARAUDEAU, P. O signo entre o sentido da língua e o sentido do discurso. In: Linguagem e discurso: modos de organização. 2. ed. São Paulo: Contexto, 2014b.

CHARAUDEAU, P. Problemas de abordagem na análise do discurso. In: Linguagem e discurso: modos de organização. 2. ed. São Paulo: Contexto, 2014a.

FAUSTO, B. História do Brasil. 2. ed. São Paulo: Editora da USP, 1995.

GARCÍA, M.; DALY, A. J.; SUPOVITZ, J. Desvelando climas de opinión por medio del Social Media Mining y Análisis de Redes Sociales en Twitter. El caso de los Common Core State Standards. Revista Hispana para el Análisis de Redes Sociales, v. 26, n. 1, 2015. DOI: http://dx.doi.org/10.5565/rev/redes.531.

GRUPO DE MÍDIA SÃO PAULO. Mídia Dados Brasil 2014. Disponível em: http:// sunflower2.digitalpages.com.br/html/reader/1 19/38924. Acesso em: 5 ago. 2015.

GUTEMBERG, A.; LEAL, Z. S. O jogo político na arena midiática: uma análise do enquadramento noticioso na cobertura das manifestações de março de 2015. In: Temática ano XI, n. 05, , p. 103-115, maio 2015. Disponível em: http://periodicos. ufpb.br/ojs/ index.php/tematica/article/view/24354/13345. Acesso em: 21 jun. 2016.

IBOPE. A internet é a principal fonte de entretenimento para $43 \%$ dos jovens, aponta IBOPE Media. 2014. Disponível em: http://www.ibope.com.br/pt-br/noticias/ Paginas/A-internet-e-a-principal-fonte-de-entretenimento-para-43-dos-jovens-aponta-IBOPE-Media.aspx. Acesso em: 10 fev. 2015. 
IBOPE. Internet é a primeira fonte de informações para 47\% dos brasileiros, aponta estudo. 2014. Disponível em: http://www.ibope.com.br/pt-br/noticias/Paginas/Internet-e-a-primeira-fonte-de-informacoes-para-47-dos-brasileiros-aponta-estudo.aspx. Acesso em: 10 fev. 2015.

IBOPE. No Brasil, maioria dos internautas são mulheres. 2014. Disponível em: http://www.ibope.com.br/pt-br/noticias/Paginas/No-Brasil,-maioria-dos-internautas-s\%C3\%A3o-mulheres-aspx. Acesso em: 13 fev. 2015.

ISRAEL, S. Introdução. In: A era do Twitter - como a ferramenta de mídia colaborativa mais dinâmica da atualidade pode revolucionar seus negócios. Rio de Janeiro: Elsevier, 2010.

LEMOS, A.; LÉVY, P. As comunidades e redes sociais on-line. In: O futuro da internet: em direção a uma ciberdemocracia planetária. São Paulo: Paulus, 2010a.

LEMOS, A.; LÉVY, P. O espaço virtual da cultura. In: O futuro da internet: em direção a uma ciberdemocracia planetária. São Paulo: Paulus, 2010 b.

MANIFESTAÇÕES contra Dilma levam multidão às ruas do país. O Estado de S. Paulo, São Paulo, 15 mar. 2015. Disponível em: <http://politica.estadao.com.br/noticias/ geral, manifestacoes-contra-dilma-levam-multidao-as-ruas-do-pais,1651418>. Acesso em: 25 jul. 2015.

PERGUNTAS FREQUENTES SOBRE OS ASSUNTOS NO TWITTER. Disponível em: https://support.twitter.com/articles/268981-perguntas-frequentes-sobre-os-assuntos-no-twitter. Acesso em: 12 jul. 2015.

PERUZZO, C. M. K. Movimentos sociais, redes virtuais e mídia alternativa no junho em que "o gigante acordou”? MATRIZES, São Paulo, v. 7, n. 2, p. 73-93, jul./dez. 2013. PRODANOV, C. C.; FREITAS, E. C. Metodologia do trabalho científico: métodos e técnicas da pesquisa e do trabalho acadêmico. Novo Hamburgo: Feevale, 2013.

PRONUNCIAMENTO de Ministros sobre as manifestações (15/03/2015). Disponível em: https:/www.youtube.com/watch?v=SUJseHEQESE. Acesso em: 1 ago. 2015.

PROTESTOS anti-Dilma reúnem mais de 2 milhões de pessoas pelo país. Jornal O Globo, São Paulo, 15 mar. 2015. Disponível em: http://oglobo.globo.com/brasil/protestos-anti-dilma-reunem-mais-de-2-milhoes-de-pessoas-pelo-pais-15602344. Acesso em: 25 jul. 2015.

PROTESTOS contra o governo reúnem quase um milhão pelo País. Folha de S. Paulo, São Paulo, 15 mar. 2015. Disponível em: http://wwwl.folha.uol.com.br/ poder/2015/03/1603286-protestos-contra-o-governo-reune-quase-1-milhao-pelo-pais. shtml. Acesso em: 25 jul. 2015.

SANTAELLA, L.; LEMOS, R. Inflow vs. Outflow: Twitter e microdesign de ideias. In: Redes sociais digitais: a cognição conectiva do Twitter. São Paulo: Summus, 2010a.

SANTAELLA, L.; LEMOS, R. Visualizando laços sociais no Twitter: o continuum na era dos fluxos. In: Redes sociais digitais: a cognição conectiva do Twitter. São Paulo: Summus, 2010b.

SOARES, F. B. A fala de Dilma sobre corrupção: análise da influência dos protestos de 15 de março de 2015 nas postagens do Facebook. In: CONGRESSO DE CIÊNCIAS 
DA COMUNICAÇÃO NA REGIÃO SUL - INTERCOM SUL, 16., 2015. Anais... Joinville, 04 a 06 jun. 2015. Disponível em: <http://www.portalintercom.org.br/anais/ sul2015/resumos/R45-0547-1.pdf>. Acesso em: 21 jun. 2016.

TWITTER completa 8 anos: veja os números da rede social. Revista Exame, São Paulo, 20 mar. 2014. Disponível em: <http://exame.abril.com.br/tecnologia/noticias/twitter-completa-8-anos-veja-os-numeros-da-rede-social\#19>. Acesso em: 01 ago. 2015.

\section{Sobre os autores}

Poliana Lopes - Doutoranda e bolsista Prosup/Capes no Programa de Pós-Graduação em Processos e Manifestações Culturais.

ORCID: http://orcid.org/0000-0002-2292-9449

Denise Castilhos de Araújo - Professora titular da Universidade Feevale, no Mestrado em Processos e Manifestações Culturais e nos cursos de Comunicação Social e Design.

ORCID: http://orcid.org/0000-0003-1055-7892

Data de submissão: 08/09/2015

Data de aceite: 28/06/2016 